PROGRAMA DE PÓS-GRADUAÇÃO EM COMUNICAÇÃO DA UNIVERSIDADE FEDERAL DE SANTA MARIA

\title{
CULTURAL DIVERSITY IN CLASSES AND WORKPLACES: THE COMMUNICATION CHALLENGES
}

Mônica Pieniz

Professora da Faculdade de Biblioteconomia e Comunicação da

Universidade Federal do Rio Grande do Sul

moni.poscom@gmail.com

University of Ottawa, October, 2019.

\section{Interviewer: I}

\section{Peruvemba Jaya: PJ}

\section{Bio}

Dr. Peruvemba S Jaya is an Associate Professor in the Department of Communication, Faculty of Arts, at the University of Ottawa. Prior to that, she has been in teaching in faculties of business in the USA and Canada. She has a PhD in Business Administration (Organizational Behaviour and Organizational Studies) from the University of Rhode Island, USA, MA in Sociology from the Delhi School of Economics, University of Delhi, India and BA (Hons) in Sociology from the University of Delhi, India.

Her research interests include the areas of gender diversity and multiculturalism in the workplace, immigration and gender, immigrant women, South Asian immigrant women's experience, immigrants' issues, interpersonal communication, identity formation and construction processes, postcolonial theory, and intercultural communication. She is also interested in ethnic media and qualitative research methodologies. She is affiliated with the Institute of Women's Studies, University of Ottawa as well as Affiliate Faculty in the interdisciplinary E Business and Technology PhD Program. She is a member of the Organizational Communication Research Group of the University of Ottawa, Department of Communication. She is currently the Regional Representative of Research Committee 32: Women in Society of the International Sociological Association and a Member of the Board of the Canadian Communication Association. 
I: Thank you so much. It's very important, not just to me, but to my country and my university. As I said the other day, we are looking for good examples in cultural diversity discussions in universities. So, you are the specialist here. It's a huge pleasure to be here with you.

Throughout your career, as a sociologist professional and professor, and researcher, you have focused on reflecting about cultural diversity, especially in the workplace, right? And among immigrant women. How did this research topic come into your life? What is your motivation for this research? Could you explain and share with us a little about some experiences in your career?

PJ: Yes, sure. Actually, when I was in India... I'm from India originally. When I was in India, I was not an academic; I was in a completely different career. I was in the insurance sector. I was an insurance middle manager or something in general insurance. And, at that time, I had never thought about this career. This happened quite by accident. But then what happened was that, after quite a few years in that industry, I realized that because it was the public sector at that time, it was very repetitive. It was not very challenging intellectually, you know, there was nothing new. And it was also very difficult because of the way the structure is - at that time at least. Now, of course, it's different. There are other companies which are private and all that, but in the public sector, it was very, very bureaucratic and you can't really do much in terms of initiatives.

For a variety of reasons - including professional - and also because certain things were happening in my life at that time, I decided that, you know, this is not going to be my path for the next... you know, I can't see myself doing this for the rest of my life. And so, I left that and came to study and do my PhD in the United States. And that was the first time I left India. It wasn't straight out of college. I had worked for a bit. I was a little older than the average student, right? That experience of moving was the first time I actually experienced that whole notion of cultural shock and all that sort of thing.

In a very real way, right? That was the beginning, actually, I would say, of my interest in all this diversity and that kind of thing. And I ended up doing my $\mathrm{PhD}$ and my topic was on identity and interpersonal communication in the workplace... 
With regard to Asian Indian Americans because it was in the United States.

I did my PhD in organizational studies in the Business School and then moved to a small college in Arkansas. Later, I moved to Canada. When I moved to Canada - and most specifically, when I moved to Ottawa - I ended up being in the organizational communication discipline. But my background in all of this was in Sociology. My Master's and Bachelor's was in Sociology in India, New Delhi. Given all this, given that - as well as my own personal experience of moving and all that - I think that was the first beginning of my interest in cross-cultural communication.

And it's one thing to say that, you know, you read about it, or that you know the theories or whatever. I didn't know the language then, but then you learn these things. But when you experience it yourself, you realize you know what you're going through, right?

That's how it started. And then when I moved to Canada, I was first in Memorial University in St. John's, Newfoundland. That was the first time, you know, I got somehow involved with a group of people or a group of scholars who were working on immigration issues - in particular with immigrant women. They were starting to work on issues with immigrant women - I don't know if you know much about this part of the country, but things are a lot more homogenous in that part of the country. It's not like Ottawa, or Toronto, or something.

I: Thank you. That was a very interesting summary because you explained the reasons.

Yes. And what is your current research about?

PJ: I still work a lot with immigrant women's issues. But I also have other, you know, sometimes, for example, it's more to do with gender diversity, multiculturalism, immigrant women, and maybe ethnic media and that kind of thing. But right now I'm working on a couple of things, for example, there's this one that I'm interested in... actually there are one or two different things that I'm working on: one would be, for example, something that I've been doing for a couple of years now where I'm looking at intergenerational communication in transnational families. I'm looking particularly at immigrant grandmothers.

So, by that I mean someone who has migrated in their lifetime from any other country to Canada, and they are grandmothers. Okay? 
They are a grandmother, but the grandchildren may have been raised here.

What are the issues? Like cultural transmission. What is important from the grandmother's perspective?

How did they deal with that interaction and those kinds of things? I've done some focus groups and interviews and all. I'm still gathering data. That is one thing.

Another thing which I just started doing last year was looking at the religious identity of South Asian immigrant women who are in Canada now. When we say South Asia, that means countries like India, Pakistan, Bangladesh, Nepal, Afghanistan, Sri Lanka, Bhutan. You know, many countries. How did they experience when they came to a different cultural space like here? How does religious identity, like, does it transform, does it remain the same, the expression of it? That was what I was interested in. I just started doing it. I presented a paper at the World Congress of Sociology last year which was held in Toronto. But I'm still gathering data on it. I'm trying to do interviews and seeing how people see these questions, you know? And when I say religious identity, I keep it very broad. It's not just about... of course there are multiple faiths, but not just faiths. It could be, like, some people can say, "Well, I'm just spiritual. I'm not religious." Or some people may say, "I'm an agnostic.”, or, "I'm an atheist". I'm trying to include different...

\section{I: Different perspectives.}

PJ: Yes, so that, broadly speaking, your expression of faith. And within South Asia, if you look at different faiths - even if it's just in India, for example, there are Hindus, there are Muslims, there are Christians, there are Zoroastrians, there are Siks - there are all kinds of faiths. I'm still gathering data. Sometimes it's hard to find people from different groups, but I'm trying to get that. And these are all South Asian immigrant women.

I: Are you still motivated about this research?

PJ: Yes, the reason is the fact that I migrated myself, right? First to the United States and then here. I feel that that experience is something that will stay with me forever, right? The thing that is interesting is that we talked about immigrant women or immigrants - although I'm a Canadian citizen now, we still see the people who moved as immigrants, right? Because it's a different experience. You spend part of your life in another country. You were not raised here, but then you 
come here at a different stage in life. And people come in at different ages as well. I think, will always remain with you. And, therefore, in a way, because I've experienced it - maybe I didn't experience all the challenges that everyone did - because it was a different path. But I do empathize with the struggles and the challenges that immigrants face. And so, in that sense, I think it's something that I'm very, very interested in and it will continue, I think, no matter how long. I don't think I see myself... It doesn't mean I won't do other things. Of course, I'm interested in anything to do with ethnicity, race, and gender, and all that - not just immigrant women. But this will be an important part of what I do, I think.

I: Okay. And relating to this, regarding your discussion about autoethnography in the paper Themes of Identity: An Auto-Ethnographical Exploration.

How do you feel about this? The good part, for sure, is empathy. But what were your personal challenges when dealing with this kind of subject?

PJ: Yes. Actually, that's a good question because autoethnography is a very controversial methodology. More and more people are using it. But, also, when we read about any methodology and we study about any methodology, we look at its limitations and we try to understand it - not just autoethnography, but any methodology or any qualitative methodology. There are pluses, but there are also challenges, right? Limitations to any method. One of the biggest challenges is that some people accuse autoethnographers as saying, “Oh, you know, you're just talking about your own life experience. How is that research?", right?

I mean, that's a valid question. Because you're getting a chance to talk about yourself and you're like, "How can that be research?" That is something that I have read even before I started doing it. I realized that that is something one has to be very, very cautious about. In other words, if I'm doing autoethnography as a methodology - which I did in this - I have to do it... This is the way I approached it. I'm not saying everybody does the same way, but that's the way I feel. I still have to have a central research question or questions, right? I have to understand whether autoethnography is the best methodology to understand that question. And I have to use my stories or my narrative in a way that helps address or is relevant to the question. If I'm talking about my story, it's not about my whole life story and all the challenges and this and that - it's more about certain portions of it which may be helpful in understanding that question. Because in this particular 
story... I mean, I did another one after this which was about immigrant women where I used autoethnography again. I thought my experience with immigration was very relevant. But here, it's more about identity. And this has to do with identity as it transforms and gets reconstructed when you move across cultures. That's what I really used it for. But in this particular paper, what I did was I used autoethnography, but I also used films as sites of analyses.

In a way, I thought, “Okay, I'm using it to understand something about ethnic identity and how identity can be transformed". Whether it's about my childhood or other experiences, whatever they may be, it has a purpose. It's not just, “Okay, I'm just randomly talking in general about my life story", because I don't think that's really relevant. The way I see autoethnography, it's just like any other methodology. You use the methodology to help you address a particular question. That's the way I tried to overcome the challenge of accusation, you know, “Oh, it's all easy. You're just talking about yourself." No, I'm talking about myself because it helps me answer or shed light on that particular topic area or phenomenon.

I: thank you for sharing that. Regarding you research and experiences - specifically in research what are the main elements to consider in gender and race studies? And what is the importance of this and other intersectionality?

And what are the challenges when it comes to these kinds of research or this field of research?

PJ: When we talk about gender and race - and I teach this in my courses and we talk about it all the time - I think it's important to use that intersectionality approach - and not just in gender and race. Because, for example, if you're looking at women's experiences, they are not universal. Not all women are the same, right? They're divided by age, sexuality or sexual orientation, race and ethnicity - there are many other things that intersect with the fact that we're all women. And then things like disability, you know, those kinds of things. Therefore, I think it's very important to understand that when we study gender, or race, or both of them together, that we need to have a very nuanced sensitive understanding.

It has to include or try to include the differences and the intersections, right?

Of the way we see people, or women in multiple contexts - including in the workplace, but also in multiple contexts - because women's experiences are colored by these kinds of dimensions, but 
also by their own life experience, you know, where they are and many different things. I think it's very, very important.

The challenge I see is that, sometimes, we say this and, of course, we recognize that it's important. But when you're actually doing research, it's very hard - often - at least I have not come across in my readings of intersectionality any rigorous methodological way to make intersectionality really like, you know, okay, we are taking into account everything. It's one thing to say you should do it. It's a big jump to how do you do it.

So that I find really difficult. I don't have the answers. I've read a lot about how people debate about it and say, "Oh, we should do it this way or that way". There are all kinds of complexities about it. But the thing is, how do you actually do it in an actual research project? I don't know.

How do you make sure that you're taking into account everything because that's what you should be doing when you are taking an intersectional approach.

But at the same time, you have to finish something, you know, that are practical things.

I: And how has your main theoretical framework been doing in your research history? Or, what are your main references?

PJ: One of the things which I have found very important, especially when you're dealing with what I call racialized minorities, meaning immigrant women - and not immigrant women from just anywhere, but from, let's say, people of color or whatever. Then often what happens is, first of all, when we say feminist approach - I've used feminist approaches. But feminist approaches are a very general term. I find that a little problematic, and I found that it was more helpful for me to use postcolonial feminist approaches because it looks at women from particular regions of the world in the context of their history, and their past, and what happened in that location. It's helpful. That is one framework I like to use.

The other, in general, is when you talk about ethnic populations or ethnocultural groups. I think it's very important. I'm especially interested in identity construction, formation and reformation. And to use theories like social identity theory, and ethnic identity theory, and those kinds of frameworks. And in the context of immigrant women, it's very important - especially in the Canadian context - we have to locate it in the literature on integration, you know, immigrant 
integration and how do people integrate into a Canadian society. What does an integration look like? What's the difference between saying integration and assimilation, you know?

And those kinds of questions. These are some of the areas that I use these kinds of approaches.

I: Okay. How was your research on cultural diversity in a Canadian university?

PJ: One thing I will say is that I didn't spend too much time in the United States after my student days. I only have the experience of Canadian universities. And the other thing is when I was out in Newfoundland, I was in a business school. Actually, it was harder because the expectation was regarding a different kind of research.

Whereas when I'm here, I actually find that, in a way, it's not easier, but at least I have the freedom or the choice to be able to do this kind of research. And I think, in some ways, it's actually - to some extent - valued because we are a multicultural society. I think people understand that it's important to do this kind of research. I mean, challenges in terms of... Yes. You still have to work...

You have to do that no matter what kind of area of research you're in. But I think there's some value. At least people realize, in Canada there is this focus, like "Okay, we're a multicultural society. We have different groups in our country." We have to learn how to understand each other whether in the workplace or in other spaces, right? There is an understanding at least - and that is important.

I: Yes. Okay. And how was the experience of editing the books Resilience and Triumph: Immigrant Women Tell their Stories...

And Immigrant Women in Atlantic Canada: Challenges, Negotiations, Re-constructions? Can you talk about it?

Tell us about your personal perspective and as a researcher.

PJ: Okay. They are both different types of books. I'll talk about the second one first because, in a way, it's easier to talk about that. I worked with this other colleague, Evangelia, who is quite a well-known scholar in immigrant women's studies. She's a full professor in Halifax at Saint Mary's University, and she's a Greek-Canadian. She's from Greece originally. I got to know her, like I told you, back when I was doing that kind of work out East. That's how I got to know her. And 
then we started doing this book project that's quite a volume. She took the lead, of course, because she was a senior, more experienced, and that sort of thing. She asked me to join her.

Because there were many people, including what I did with another person, we were looking at immigrant women's issues in that region of Atlantic Canada. There are four Atlantic Canadian provinces: Nova Scotia, Newfoundland and Labrador, Prince Edward Island, and New Brunswick. These are considered the Atlantic provinces.

We were looking at a lot of people who had done research funded by that Centre - which I told you about, the Metropolis Centre.

Anyway, the idea was to collect all that data in a book. It was a very interesting learning experience for me because I had not done that before. I learned a lot just by working with her and going through the process of how it's done, like how to get the publisher to approve that. It was a peer reviewed book. We, as editors, also looked at the writing and we provided feedback and the whole things was, again, looked at by another group. It was very interesting and very rigorous, but also very, very enlightening in terms of the process: the review process, the writing process, and the editing process. I thought it was a great experience for me because I learned a lot.

And she's very experienced, very thorough, and very detail-oriented. There are many things that I learned just by collaborating with her.

And, of course, she took the lead. So, that was one. The second one - which happened in 2015 was a completely different experience because it is not an academic work.

You might've seen it. If you've seen it.

What we did was... This was actually the first person whose name is there, Rashmi Luther. She was the one who took the lead. She is now retired from Carleton University. But she had wanted to do something like this. Her background is on social work.

And she said that what she wanted to do... you know, this particular press that published it, there was a book that came out I don't know when before this, which was about Canadian women's stories in general.

I: Yes. Not just academics? 
PJ: No, just anybody. But here she was like, "Okay, we need to do something about immigrant women and, in particular, racialized immigrant women - meaning, women of color. But her vision was that it's not about academic research; it's about people's stories. The stories could be - you'll see if you look at the book - just an account of something that happened with you, or your reflections or thoughts on your experience as an immigrant. It could also be... in some cases, there were people who wrote poetry. Or they made up a story like a narrative or a fiction. There are different formats, and we give them that. We just said, "We want you to talk about that". And we asked them about and related it to the idea of feminism because, sometimes, what happens is - and I don't know if you'll agree with me - we find it in many countries like India, which is where I'm from, that there are a lot of strong women. Whether they are mothers of grandmothers, or other people we see in society, they are not academics - they're just people. They are women who are living their lives, but they are very strong in the way they face their lives.

I: Yes. For sure.

PJ: In a way, you could call them feminists. But if you ask them whether they are feminists, they may say, "What is that?"

They don't know or they don't even think about it. We wanted to keep it broad. And if you look at the team - we had a team-based approach. She was the leader, but there were seven of us who coedited. And each one of them... Rashmi Luther was an academic, I was an academic, Vanaja Dhruvarajan was an academic. But all the others were people who worked in the community...

In immigrant women's organizations in Ottawa.

I: That's amazing.

PJ: Yes. She was the one who brought all of us together, and she felt that it should not be like an academic work. That's why it needed to be more broad-based. And then each of us collected all these stories... it took us a long time because we had to keep sending calls and sometimes people are reluctant to talk about themselves. We had to try to make it as broad-based as possible across Canada because we wanted to hear from different groups, people from different parts of the country. And then the idea was to organize it into teams, so each of us took a team or something like that. That's how it came out. And the main thing that I remember about this is not just the 
publishing or the stories that came out great, by the way, but the process was also very, very rewarding. I think it took us about three to four years maybe. What happened was that we would have periodic meetings - usually in one of the immigrant women's service organization - and then we would just sit around and talk. You had to be there at the meeting to really understand. Somebody looking in would say it was chaos because we were all talking and interacting with each other at the same time. We were sharing our own experiences. It was almost like... I don't know how to explain it... like very emotionally rewarding, enriching into one's self too...

I: I can imagine... From your long experience in this area - as you talked about this book and your personal experiences, your expertise, your knowledge - how should we discuss cultural diversity in class in the undergrad and Graduate programs?

And how should we prepare students for this cultural diversity challenge in society, in different organizations, and context around the world? This is our main challenge in Brazil nowadays, as a professor.

PJ: Generally speaking, when we talk about how we discuss cultural diversity, one of the ways I've found very helpful and it has been productive, is that, for one thing, of course we have a lot of theories and this and that, and we talk about that, right? It's important, too. But just talking about that, sometimes I find students are not that engaged. They think it's too abstract.

Conceptually speaking, it's too dry or, you know, what does this tell us about real life? They lose interest sometimes. What I often say, especially about cultural diversity research, is don't think about the theories first. Try and relate it to your own experience, your own life experience.

Or it doesn't have to be an experience. It could be your family background, or what you see in relation to your group of friends maybe, or in relation to your family, or perhaps to a church or temple group that you belong to, or whatever. Those kinds of things. The reason is that many of our students come from different backgrounds.

We're able to do that. Once you say that, then people start thinking, "Oh, okay. I grew up in Canada." They'll say, “I'm Canadian. I grew up in Canada. But my parents came from....', I don't know, maybe they came from Chile or Brazil. Maybe they came from India, China. Or it could be that maybe not your parents, but your grandparents came from Ireland or somewhere else. Once 
they make that link, they understand, "Okay, these are my roots". And then they relate it to their own experiences and they're able to connect with the material more. I found that very helpful. That is like a broad answer.

I'm going to give you two examples, one of an undergraduate class. Last fall, fall of 2018, I developed a particular course which is like a fourth-year undergraduate course, a seminar course you know, special topics. We can do that if you want.

And it was about immigrant women in Canada.

Because I wanted to do it. It was the first time I tried that and the department approved it, and then I was able to do it. And what I noticed was - and I'm not exaggerating and neither am I boasting that it was an excellent experience in different levels. Why? Because, first of all, the group was not very big, so that always makes for better discussions than if you have a large class, right?

Secondly, every person in that group, for one thing, I don't know how it happened that it ended up being all female students. Perhaps it was the topic? Maybe it was because of that.

But every one of the students in that class, at the end of the class, it was almost like an emotional journey for them.

And the reason is that, most of them, had not migrated in their lifetime. They were not immigrants, but they were children of immigrant parents.

And a lot of the things that we were reading about... actually, you know what I used? I used both these books.

\section{I: Okay. That's amazing!}

PJ: In that class. And they are very different things: one is an academic book and the other is more like stories, right? But when they read all this, and they had a lot of presentations. They had to make summaries, they had to discuss and do a lot of talking. But one of the things that came across was that they all could relate to a lot of the issues because they had seen it first-hand - sometimes with their mothers or their grandmothers - in many cases with their mothers. By the end, sometimes you could almost feel that they would get very angry because we talked about the challenges that 
immigrant women faced in, for example, employment. Or challenges they faced in regard to integrating into the Canadian society.

Or even cultural differences between generations and things like that. Many things they were able to relate to. And you could see it in their own homes. In fact, they told me they used to go home sometimes and discuss the class with their mothers.

I thought that was really nice. It went beyond the classroom, right? And you feel they were impacted with something at a deeper level.

So, I thought it was very rewarding personally.

That was one opportunity. The other course that I'm going to talk about is at the graduate level, at Master's level - which I'm teaching now, but I've taught it a few times. It's called Diversity in the Workplace: Communication Challenges.

That is another class which I found extremely rewarding, first, because of the material - but it's not just the material. Again, what happens is that we usually get a group of students there who are quite... in the MA program we get people from different parts of the world sometimes. And so, we end up having - maybe because of the topic, I don't know, and they get attracted to that - people from different countries. You know, people who would come from different African countries, or China, or whatever. And they have just come in. They come for their studies, right?

I usually say that you have to do the readings and we have a structure and all that but, beyond that, please also talk about your experience with diversity - not just in Canada, but how is it in your home country? Because sometimes that helps other people... A lot of students were raised here and they may not have that understanding.

It opens up the flow. And, again, I found a very animated discussion there. Of course, we have our structure, but it goes beyond that. Sometimes we have some very lively discussions and debates.

And then, of course, there are student presentations and so on. I have found both of these classes extremely rewarding and it's something that I would continue to do because I find it's... and they come back and also find it very interesting. You can see that they are there because they want to 
be there because they are really interested - because of the nature and because they are invested in the topic, you know?

And then because we talk about different aspects of diversity. It could be, you know, racism, gender differences. We talk about age issues. We talk about disability. I try to create a welcoming environment and sometimes we find people... students will identify, "Okay, I have a disability." They don't have to say it in a public forum, but they will say it and give examples from their experience. Or they'll say, “I'm a gay person and this is the way things affected me in the workplace" or, you know, "The challenges I faced" and things like that. We talk about a lot of those things and how you overcome those, right? And what are the issues in the workplace context. Especially in the workplace. You know, what exactly happens. I find it's always a good discussion.

I: What are the challenges of communication when it comes to cultural diversity in the workplace? How do you see the communication professionals in this issue more specifically?

Specifically, you as a sociologist teaching in the Communication Department here, your point of view is very important to me. How do you feel about it and what are the challenges of communication when it comes to this topic of cultural diversity in the workplace, especially imagining this professional as a PR or a journalist in a company?

PJ: Yes. Yes. I think I what especially happens with our students are two things: one, we are in Ottawa which is the capital of Canada, right? A lot of the times, a lot of our students - if they find jobs anywhere in Canada - end up or they are sometimes already working for the Federal government.

\section{I: Okay.}

PJ: Because we also have a co-op option. It's not just co-op; sometimes they're working part-time and they're doing their Master's or something. One of the things I think is that when you are in a workplace anywhere in Canada - but here we are in the capital city - we are also a bilingual institution and there are two official languages in Canada.

There are many things here, you know. The French-English dynamic goes back to the History of Canada, right? 
How Canada came into existence. Then, on top of that, we have the first nation's indigenous people. Then we have this whole idea of multiculturalism, in particular about newer immigrants, you know, people coming from different countries. There are a lot of things.

Going on. I think that, no matter which field you are in but, certainly in communication... let's say you're a communication professional in the Federal government, you're in health communication, or some other work in relation to political parties or a foreign political party. It doesn't matter what it is or what field they're in. The point is, they all realize - and we see this in class discussions that because we are located in Ottawa, because we have this bilingual element, because we are also a country recognized more and more as a multicultural country, the workplace is quite diverse.

And if it's not diverse, then they feel that it should be diverse. But, also, they know that there are people there who are from different backgrounds. I think that, whatever they study, it will actually help them in a practical way. To understand that and to be sensitive to that.

To deal with different people. Because you can just talk about it, but when you realize it and you discuss it and you think about it - and we talk about it in class where we try to understand these different theories and the actual experiences - then together that helps. Personally, I think it's very relevant.

In fact, even in the intercultural communication class which I taught to the undergraduates, some students actually said, "Oh, we should have this as a mandatory course for everybody." They said it themselves.

I didn't say it. They said it.

There is a history there somewhere. Except for the first nation's people who you can call the original people, the rest, everyone is an immigrant. It's a matter of how long have you been here. That's all.

We know that, but we do have challenges. It's not like we're perfect. But I think, at least, that we have a recognition...

And that we're willing to talk about it. That's the thing.

I: Yes. Talk about it. I think it's the first, the main step. 
PJ: It's not like we have all the answers, all the solutions, or that we're a perfect society. I would not say that. But I think there's a lot of focus and thinking that, "Oh, we need to think about this. We need to talk about this." And also recognizing when something goes wrong and calling it out, right? At least we're discussing. We don't hide it. We say, “Oh, this was not good. This should not have happened."

Especially in the workplace. And this could mean things like, you know, it's not just about race and ethnicity. What if you had a colleague who's Muslim and wears a hijab? Or who needs time to pray?

While they're working? Or it could be somebody else who practices a different faith and then needs some time because of a particular holiday, for example, right? We, as humans... Not everyone believes in the same thing. Not everyone has the same kind of practice. Not everyone belongs to the same racial background, ethnic group, etc. These kinds of differences are very visible now in our society, and these are the people who are going to be the future. A lot of them, maybe, are young people. But they are going to enter the workforce and they are going to be the future of Canada. It's a very real thing. This is the demographic composition of the country.

Also, if you look at the demographics, we're also an aging society, there are more older people. And, through immigration, we're getting all the young people more. In some provinces, the rate is actually declining but, at the same time, because we're having a lot of immigration, we're getting more diverse groups.

These are different things that are happening in the social structure and social fabric of Canada. And so, the recognition of that, I think, is very important. It's no longer about diversity being something that we just studied about. It is something you may experience in everyday life.

Because whoever you meet, you don't know what happens in the workplace or how you have to interact with different people, and how that understanding and sensitivity will help you interact with that individual.

I: Yes. And, finally, the last question. How do you see the responsibility of communication professionals? What do you think is our duty? You talked about that already, but in terms of an 
ethical position, what would be our responsibility as communication professionals in a more formal way when dealing with culturally diverse environments?

PJ: Well, as a professor, as a teacher, I try to do that in my teaching, right? I try to do that in my research. I can learn more but, also, in general, to cultivate... like, even in the classroom, you're the teacher, but you also have to make sure that everyone feels comfortable in the classroom.

I try to create an environment which is open to different viewpoints because think that if we cannot speak freely enough in the classroom, then there is something really wrong with the way we are teaching and also with the environment. I'm talking about it from my perspective as a teacher and as a researcher that you provide the environment and the space for the students and for the people who are in the classroom.

Or if you're doing research and you're dealing with different people from different backgrounds, when you talk to them and you're doing primary research as you're interviewing a focus group or whatever, you have to do it in a respectful manner in a way that you're sensitive to their particular situation. These are some of the things that I can think of. Of course, if you're creating that environment in the classroom then, hopefully, when they finish their degree and they go back to work somewhere, they carry that with them and maybe they transfer that in their own interactions.

\section{References}

LUTHER, R., MAZIGH M., DHRUVARAJAN, V., KOTANI, Y. JAYA, P., JAMA, I., SPENCER, L. Telling Our Stories: Triumphs, Resilience and Struggles. Second Story Press and Feminist History Society Canada: Ottawa, 2015.

TASTSOGLOU, E. \& JAYA, P. Immigrant Women in Atlantic Canada: Challenges, Negotiations, and Re-Constructions. Canadian Scholars Press Incorporated, The Women's Press Canada: Ottawa, 2011.

JAYA, P. Themes of Identity: An Auto-Ethnographical Exploration. The qualitative report. Volume 13, Number 3, 2011 (745-763). 


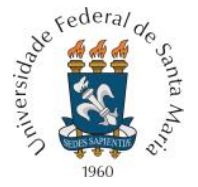

PROGRAMA DE PÓS-GRADUAÇÃO EM COMUNICAÇÃO DA UNIVERSIDADE FEDERAL DE SANTA MARIA

Original recebido em: 10 de novembro de 2019

Aceito para publicação em: 16 de março de 2020

\author{
(c) (i) (9) (2) \\ Esta obra está licenciada com uma Licença \\ Creative Commons Atribuição-NãoComercial-CompartilhaIgual 4.0 Internacional
}

